1 Faculty of Geography, Lomonosov Moscow State University, Moscow, Russia

*Corresponding author: spkoshkin@gmail.com

\title{
WIND FARMS - COMBINING ENERGY AND ECOLOGICAL PERFORMANCE IN CRIMEA
}

ABSTRACT. Renewable energy use is spreading worldwide presenting the future of the power engineering - its renewable resources and low ecological impact characterize one of the best technologies to support permanently growing energy consumption and contribute to sustainable development. But its development is sometimes hampered by lack of suitable technologies and strong positions of the competing conventional energy production. Moreover, critics emphasize such problems of renewable energy use as unstable energy production, complicated connection to power lines, some ecological problems. To prove its efficiency renewable energy development needs support by relevant resource and ecological assessments. This paper presents our research concerning wind farm location issue regarding both production efficiency and minimal ecological impact. Our field research in Crimea was directed at on-site assessment of wind farm location efficiency as well as studies of public opinion concerning local wind farms and wind energy use in general. It was found out that Crimean wind farms have controversial location efficiency related to its power production. But their ecological impact was minimal proved by both on-site measurements and sociological survey results. It was also found that wind turbine noise impact had a very complicated character, but had no significant ecological impact.

KEY WORDS: wind energy, wind farm, placement, ecological impact, Crimea

CITATION: Sergei P. Koshkin and Tatiana M. Krasovskaya (2018) Wind Farms - Combining Energy And Ecological Performance In Crimea. Geography, Environment, Sustainability, Vol.12, No 1, p. 88-103

DOI-10.24057/2071-9388-2018-51

\section{INTRODUCTION}

Nowadays economic activities are promoted by power engineering development which ecological footprint may be clearly determined. Turn to renewable energy use may help to solve both problems. But renewable energy use also has a certain negative ecological impact, depending mainly on technological issues. Combining energy and ecological efficiency is a very complicated task. We tried to characterize wind farms at our study area in this respect using world experience in efficient work of wind farms and minimi- zation of wind turbines environmental impact. We avoid discussion of financial aspects of wind farms construction and operation presenting quite different aspect of efficient wind energy use.

\section{Background}

The principle factor controlling wind farm energy generation and environmental impact at a local level of wind energy use is its location in the environment. .Efficiency of electricity generation is defined by two issues: wind power potential depending on meteorological parameters and inter- 
dependent work of wind turbines since each wind turbine (being a physical obstacle) produces a turbulent trace in the airflow. Such effect is noticeable at some distance from a wind turbine depending on a rotor diameter (UK Department of the Environment 2007; Samorani 2010; Meyers and Meneveau 2011).

Being at the top list of environment-friendly power production wind energy production still has some negative impact (Fig. 1) (Rabl and Spadaro 2005). Minimization of wind farm ecological impact requires detailed field studies of local landscapes, fauna, human health.

Environment impact also depends on a stage of wind farm project implementation. At the construction stage mechanical disturbances are typical and might be harmful for local land use (Brannstrom at al. 2017), while there is only contradictory visual impact at the operation stage (Filin 1997; NZWEA 2017). Impact on animals differs a lot: from physical contact (birds, bats, insects) (AWEA 2006; Baerwald at al. 2008; Dillo and Tronstad 2012) to low-frequency vibrations and noise (livestock in stalls, meadow and desert fauna) and ground vibration (soil meadow and desert fauna) (Mikolajczak at al. 2013; Lopucki and Perzanowski 2018). Human impact is connected with low-frequency vibrations and noise, but it should be a long-term impact to have any effect (Leventhall 2003).
Noticeable impact on microclimate is possible only in case of large wind farms, where decreased annual wind speed leads to larger amplitudes of daily temperatures (Keith at al. 2004; Bettex 2012).

\section{Study area}

Our field research was conducted in September, 2017 in Crimea. This region was chosen as one of the best areas in Eastern Europe to develop wind energy use. Besides the Crimean Peninsula has sufficient wind (and solar) resources, this territory has already several wind (and solar) power stations (Fig. 2) which generated 25\% of Crimean electricity in 2015 (MERF, 2015). But Crimean power production covered only 20\% of local consumption (MERF, 2015). Considering this fact and problems with energy transport from other regions (RIA News Crimea 2015; Kommersant 2016; Regnum 2017; SM news 2017), the necessity of Crimean local power production is obvious. And this gives a chance to wind energy production development.

Nowadays seven wind farms (103.9 MW of total installed capacity) are being operated in different parts of the peninsula (Fig. 2). We have chosen three wind farms to study different models of wind turbines used for power production: Ostaninskaya, Presnovodnenskaya and Sakskaya (Mirnovsky site) wind farms (Table 1).

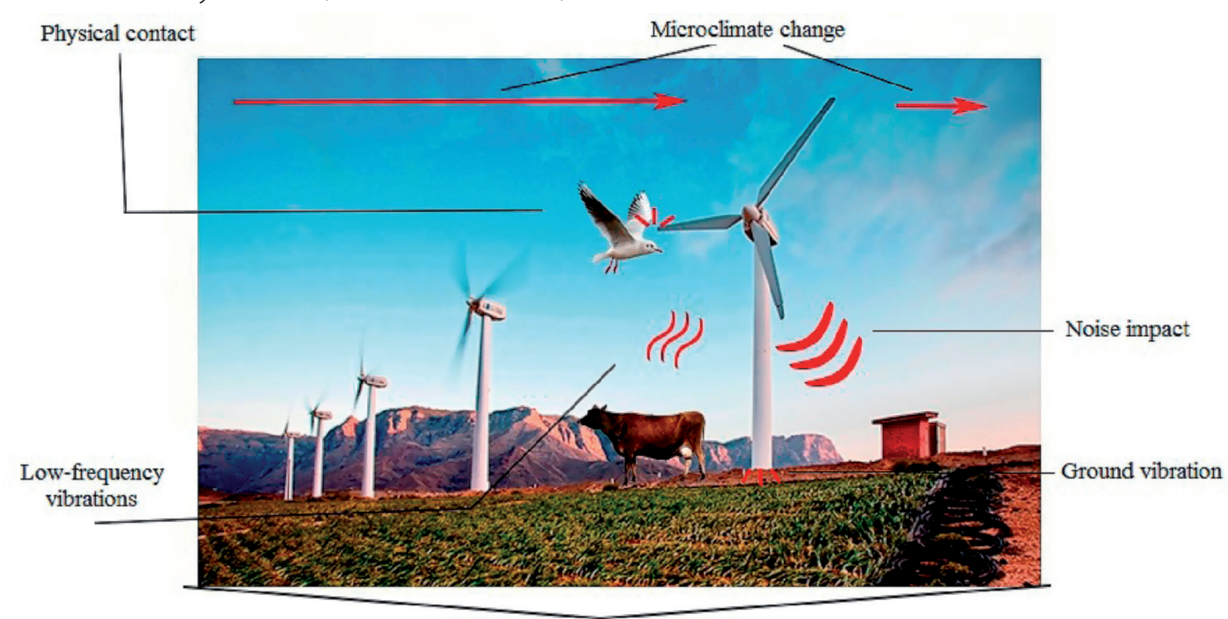

Visual impact on the landscape

Fig. 1. Schematic visualization of wind turbine environment impact 
Table 1. General characteristic of the studied wind farms

\begin{tabular}{|c|c|c|c|c|c|c|}
\hline \multirow[b]{2}{*}{ Wind farm } & \multirow{2}{*}{$\begin{array}{l}\text { Location, } \\
\text { operation } \\
\text { period }\end{array}$} & \multicolumn{4}{|c|}{$\begin{array}{l}\text { The characteristic of installed wind turbines } \\
\text { (SUE Crimean Generating Systems, 2017) }\end{array}$} & \multirow{2}{*}{$\begin{array}{c}\text { Total } \\
\text { installed } \\
\text { capacity }\end{array}$} \\
\hline & & Model & Capacity & $\begin{array}{l}\text { Tower } \\
\text { height/ } \\
\text { Rotor } \\
\text { diameter }\end{array}$ & Amount & \\
\hline Ostaninskaya & $\begin{array}{l}25 \mathrm{~km} \text { to the } \\
\text { west from } \\
\text { Kerch town, } \\
1 \mathrm{~km} \text { to } \\
\text { the south- } \\
\text { west from } \\
\text { Stantsionnoe } \\
\text { village: } \\
\text { since year } 2013\end{array}$ & $\begin{array}{l}\text { Furhlander } \\
\text { FL2500/100 }\end{array}$ & 2,5 MW & $98 / 100 \mathrm{~m}$ & 10 turbines & $25 \mathrm{MW}$ \\
\hline \multirow{2}{*}{ Presnovodnenskaya } & $\begin{array}{l}25 \mathrm{~km} \text { to the } \\
\text { west from } \\
\text { Kerch town, } \\
2 \mathrm{~km} \text { to the }\end{array}$ & $\begin{array}{l}\text { USW } \\
56-100\end{array}$ & $107,5 \mathrm{~kW}$ & 18/17 m & 52 turbines & \multirow{2}{*}{ 7,4 MW } \\
\hline & $\begin{array}{c}\text { Stantsionnoe } \\
\text { village: } \\
\text { since year } 2006\end{array}$ & $\begin{array}{l}\text { AN Bonus } \\
600 \mathrm{~kW}\end{array}$ & 600 kW & $50 / 44 \mathrm{~m}$ & 3 turbines & \\
\hline \multirow{2}{*}{$\begin{array}{l}\text { Sakskaya (Mirnovsky } \\
\text { site) }\end{array}$} & \multirow{2}{*}{$\begin{array}{l}21 \mathrm{~km} \text { to the } \\
\text { north-west } \\
\text { from Evpatoria } \\
\text { town, } 2 \mathrm{~km} \text { to } \\
\text { the north from } \\
\text { Krylovka village: } \\
\text { since year } 1998\end{array}$} & $\begin{array}{l}\text { USW } \\
56-100\end{array}$ & 107,5 kW & 18/17 m & $\begin{array}{l}155 \\
\text { turbines }\end{array}$ & \multirow{2}{*}{$18,46 \mathrm{MW}$} \\
\hline & & $\begin{array}{c}\text { Turbowinds } \\
\text { T-600-48 }\end{array}$ & 600 kW & $50 / 48 m$ & 3 turbines & \\
\hline
\end{tabular}

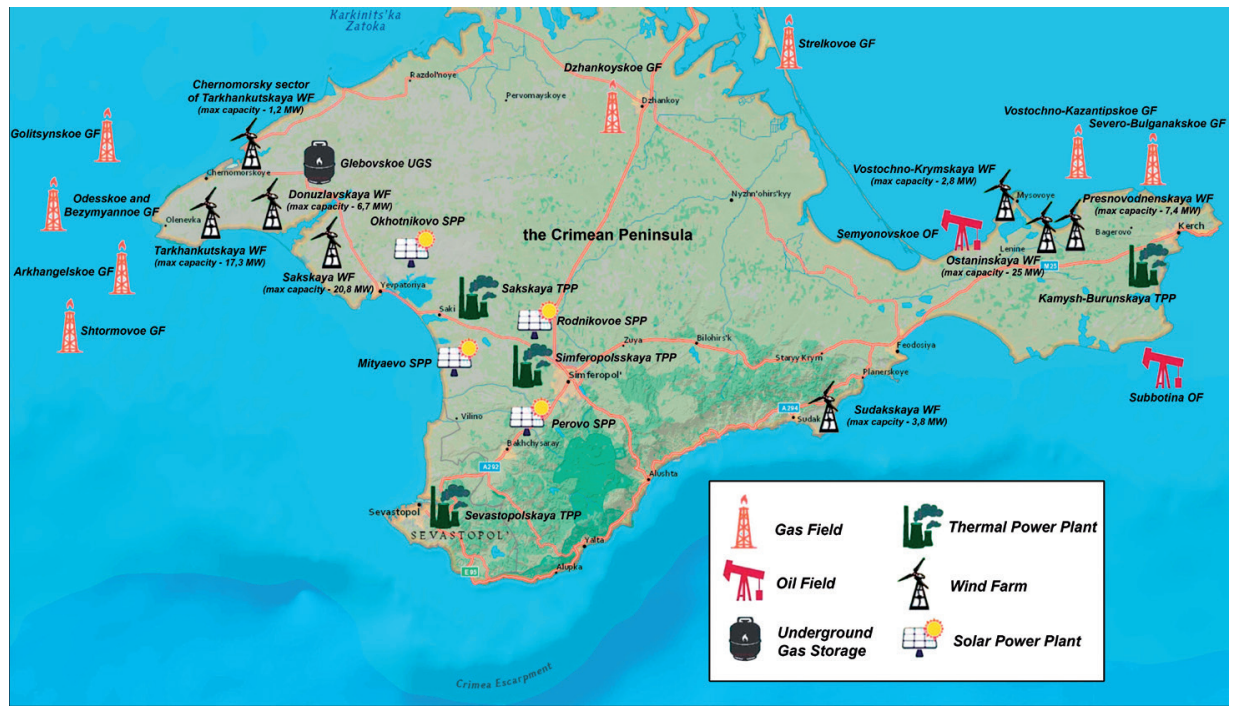




\section{MATERIALS AND METHODS}

To characterize the efficiency of electricity generation on the selected wind farms we assessed wind power potential at wind farms areas. The assessment data included Gismeteo meteorological data, relief (SRTM model) and land use pattern studies. The results were compared with projects data. Land use and wind farms schemes were received from IKONOS images (1 $\mathrm{m}$ resolution). Wind power potential of wind farms areas was calculated using the following formulas (Elistratov, Kuznetsov, 2003):

$\mathrm{U}$ - wind speed at wind turbine height,

$$
U=U_{a} \cdot K_{h}
$$

$U_{a}$ - wind speed at anemometer height (10 $m)$,

$\mathrm{K}_{h}$ - height adjustment factor, where

$\mathrm{H}$ - wind turbine height,

$$
K_{h}=\left(H / h_{a}\right)^{m}
$$

$h_{a}$ - anemometer height $(10 \mathrm{~m})$,

$\mathrm{m}$ - exponent which is taken depending on the wind speed at the height of anemometer

During the field research we visited the selected wind farms to measure noise and visual impact (loss of aesthetic landscape features) of wind farms and impact produced by specific wind turbine models. Noise measurement was provided by standard methods (SWL' type) using handheld SLM². The received data was imposed on a land use map to define impact zones of wind farm. Visual impact of wind farms was characterized using aesthetical landscape science methods (Nikolaev 2005) and visual pollution methods (Filin 1997). We followed guidelines for visual impact assessment presented at Fig. 3.

At the same time, we conducted sociological survey asking local people about noise and visual impact of the neighboring wind farms and their general view on wind energy development in the region (Fig. 4).

Visual resources(natural, cultural,technogenic

Visual quality (natural harmony, cultural order)

Fig. 3. Visual impact assessment process (Wilson 2002)

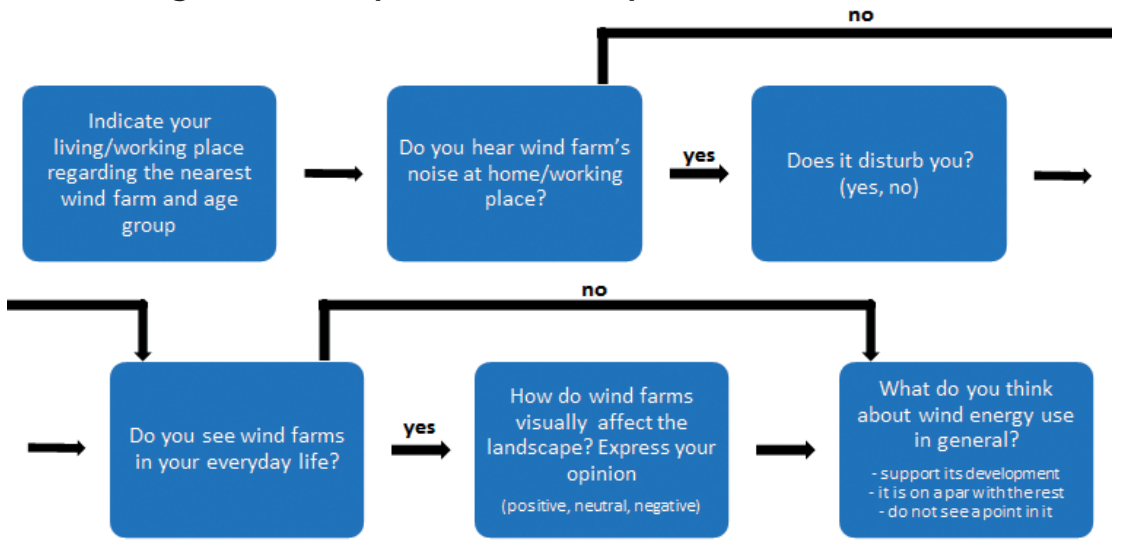

Fig. 4. The principal scheme of our sociological survey 


\section{RESULTS AND DISCUSSION}

Each of the selected wind farms was characterized regarding their locations (affecting its energy production efficiency) and visual impact. Noise pollution was measured for each type of wind turbine models.

\section{Location factors}

Electricity generation efficiency of wind turbines highly depends on their location regarding wind power potential of a territory. Properly positioned modern wind turbines, being equipped by yaw system, may effectively and independently produce electricity permanently in case of strong enough winds of different directions.

But the situation changes when we deal with a wind farm consisting of two and more wind turbines. Every wind turbine causes air turbulence reducing wind power potential at some distance. That is why wind turbines should be placed to avoid negative affect on each other. If it is impossible, because of landscape factors or land space deficiency, the best variant is location directed to reduce negative effect from turbulent traces: to meet the maximal negative effect at the rarest wind direction minimizing it at the rest directions.

Current situation in wind energy development (which is confirmed in our research as well - see below) is controlled by wind turbine manufacturers trying to maximize sales while wind project developers try to receive maximal financial investments and minimize expenditures on rent/purchase of land sites (Mitchell 2014). As a result, the maximal possible number of wind turbines is placed at the minimal area rising economic efficiency of a project, but only at the stage of construction. A territory purchased by wind farm owners consists of wind turbine sites and linking roads. The rest belongs to municipal property (FSSRCCRF$^{3}$ 2018).
Receiving maximal economic efficiency at the construction stage, wind project developers reduce it in future as far as the installed wind turbines experience impact of turbulent traces and generate less electricity. Recent research (based on turbulent trace and land cost data) showed different data considering economically effective distances between wind turbines - from seven (Samorani 2010) to fifteen (Meyers and Meneveau 2011) rotor diameters of an installed wind turbine. In our research we used this range (seven to fifteen rotor diameters) and local wind roses to characterize selected wind farms layout and to assume the most optimal scheme considering land accessibility.

Sakskaya wind farm (Mirnovsky site). Mirnovsky site of Sakskaya wind farm is situated near Lake Donuzlav in the western flat part of the Crimean Peninsula. Wind farm territory and its surroundings consist of partly abandoned and flat fields with fragmentary tree rows, 5-10 m height which may cause turbulence affecting USW 56-100 wind turbines during western and southern winds (Fig. 5).

The distances between this wind farm turbines (Fig. 5), partially mismatch optimal 119-225 m for USW 56-100 wind turbines and 336-720 $\mathrm{m}$ for T-600-48 wind turbines. General orientation of wind turbine rows is north-west/south-east - it is the rarest wind direction there. We supposed that the wind rose of the territory had been probably taken into account when designing Mirnovsky site, but there was obvious minimization of land use expenses. This caused losses in electricity generation by wind turbines - all of them were affected by turbulent traces from neighbor ones.

\section{Ostaninskaya and Presnovodnenskaya wind farms.}

Ostaninskaya and Presnovodnenskaya wind farms are located in the east and hilly part of the Crimean Peninsula near

\footnotetext{
${ }^{1}$ Sound Power Level

2 Sound Level Meter)

${ }^{3}$ The Federal Service for State Registration, Cadastre and Cartography of Russian Federatio
} 


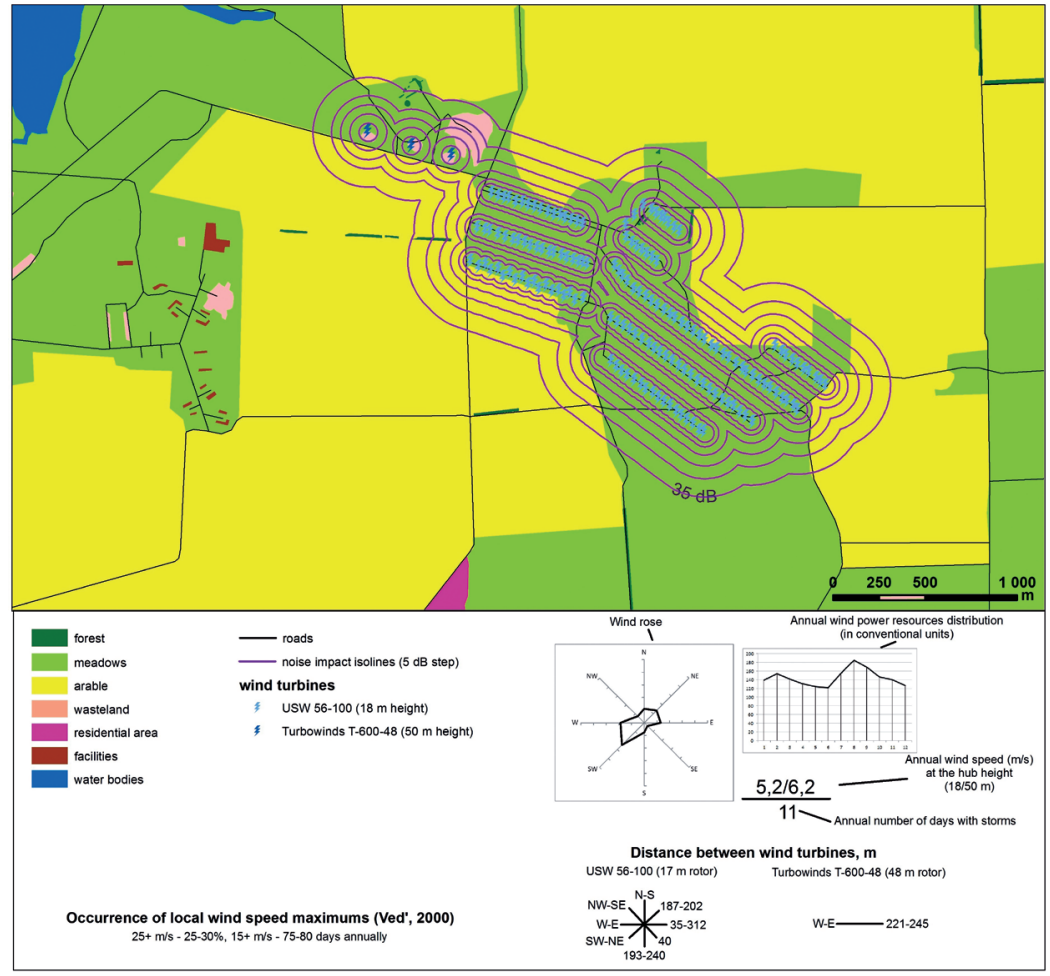

Fig. 5. Situational map at Mirnovsky site, Sakskaya wind farm

the Kazantip bay of the Sea of Azov (Fig. 6). While Ostaninskaya wind farm turbines were scattered over smooth meadows around Zelenoyarskoe water reservoir, Presnovodnenskaya wind farm stretched along the Kamenistyi Ridge at the southern border of the Kerch reservoir valley the best place to locate wind farm in this area considering active recreational use of the nearby seacoast.

Distances between wind turbines of Ostaninskaya and Presnovodnenskaya wind farms (Fig. 6) (as well as for the previously discussed wind farm), did not match the following optimal distances - 119$255 \mathrm{~m}$ for US 56-100 wind turbines, 308$660 \mathrm{~m}$ for AN Bonus and 700-1500 m for FL2500/100 wind turbines. There might be different reasons for each case.

The row of Presnovodnenskaya wind farm turbines changed its direction from west/ east to north-west/south-east. Winds of these directions were the rarest for the area (70 days per year for each direction). We consider this fact as coincidental, be- cause the line of wind turbines was determined by the Kamenistyi Ridge. The top of the ridge was the most optimal position for wind turbines of Presnovodnenskaya wind farm, but the Kamenistyi Ridge length was much longer than the wind farm. We think that it was possible to prolongate the wind turbines row further to the east to reduce wake effect.

Arrangement of Ostaninskaya wind farm turbines was generally chaotic. Some wind turbines directed north-east/southwest or north/south experienced mutual trace effect It was particularly important as far as these directions were the most frequent for local winds. We suppose that local wind rose might have been analyzed during this wind farm project development, but developers probably considered turbulent traces shorter than they were if to regard the latest research data. (Samorani, 2010) (Meyers, Meneveau, 2011). Chaotic arrangement of Ostaninskaya wind farm may be as well the result of land use expenses minimization. We found out that insufficient research 


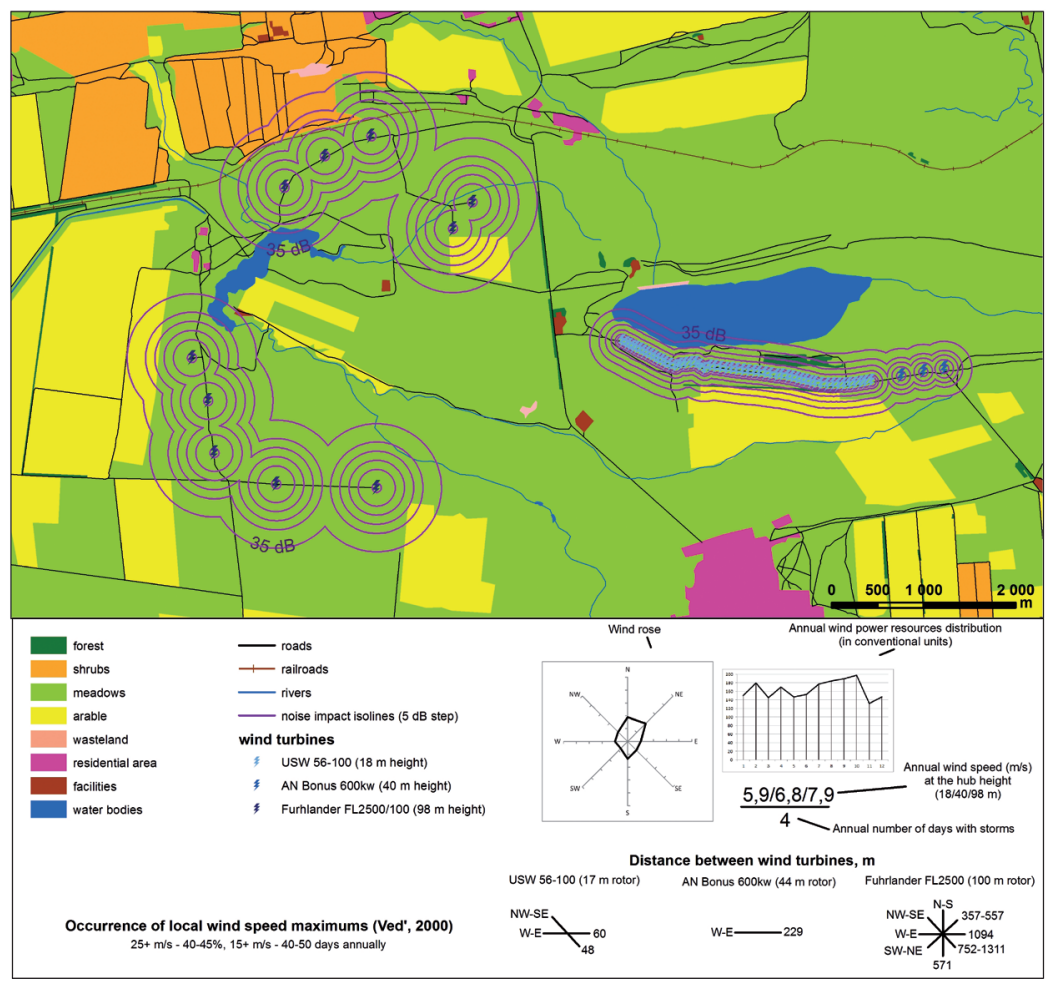

Fig. 6. Situational map of Ostaninskaya and Presnovodnenskaya wind farms

of technological features of wind farms operation (and sometimes even meteorological factors as well) were typical for the studied wind farms. Mirnovsky site of Sakskaya wind farm might be identified as an example of controlled arrangement while Presnovodnenskaya wind farm presents the result of favorable location choice. The arrangement of Ostaninskaya wind farm is the most debatable because of its random arrangement.

\section{Noise impact}

Our research demonstrated that noise impact of the studied wind farms did not influence the surrounding inhabited area (Fig. 5-6). Background noise in still weather was measured beyond the limits of the noise impact zone and it was about 28-30 dB. In case of wind turbine blades rotation following the blowing wind which produced noise itself, sometimes even muffling the noise from a wind turbine even at its base, we considered background noise as different from the above mentioned value: the blowing wind sound was more than 30-35 dB (up to $70-75 \mathrm{~dB}$ ). So we regarded $35 \mathrm{~dB}$ as the minimal level of noise impact from wind turbines in our research (Fig. 5-6).

The highest noise was produced by 18 $m$ height wind turbines USW 56-100 (70 $\mathrm{dB}$ at the turbine base). It might be explained by two factors - the nearest distance from the blades to our SLM and design features. While the major sound from the rest wind turbine models was the sound of air cutting produced by their blades, USW 56-100 wind turbines filled the air with the sound of rotary elements friction inside the turbine. It was detected on both Mirnovsky site and Presnovodnenskaya wind farm and may be explained by mechanisms worn as well. Meantime, the largest radius of noise impact was recorded from the $98 \mathrm{~m}$ height FL2500/100 turbine - about 700 meters. Probably this is explained by the largest size of blades (100 m diameter). The radius of noise impact from two other wind turbine models was about 300 meters. 
We have detected some features of noise impact from wind turbines of different size. While noise from $18 \mathrm{~m}$ height USW 56-100 turbine decreased permanently with distance from its base, $50 \mathrm{~m}$ height AN Bonus $600 \mathrm{~kW}$ and T-600-48 turbines had $55 \mathrm{~dB}$ a sound 'plateau' at the distance of $50-60 \mathrm{~m}$ from the base; $98 \mathrm{~m}$ height FL2500/100 turbine produced the loudest sound at the distance of 50-75 m from the base (Fig. 7).

Such differences in noise patterns from turbine to turbine may be explained by their design and the main source of noise. 50 and $98 \mathrm{~m}$ height wind turbines produced the loudest sound by fast blades tips heightened from the base in case they moved downward provoking noise peaks right under them at the place of their location. Moreover, as far as different-origin sound had different frequency, noise spreading pattern was also different (Fig. 7).

Back to the fact that blowing wind was capable to muffle wind turbines noise it should be mentioned that the noise of air cutting from rotating blades was very similar to that of simultaneously blowing wind. Thus, we may suggest that noise impact from wind turbines at the site was not so much as diagrams showed because basic wind sound was not regarded.
We think it is possible to install wind turbines closer to residential areas than it is done now but in case of adequate assessment of on-site noise structure and distribution. As far as the rest Crimean wind farms are concerned, we extrapolated the received results of noise studies for their territories. In the result, it was found out that one of the rest wind farms had noise impact on inhabited area (Fig. 8). Considering noise sound from wind turbines - about 500-1000 Hz (Bolin at al., 2011), the permitted noise level for residential areas in the Crimean Republic according to local health standards (SCSES$\mathrm{RF}^{4}$, 1996) - $40 \mathrm{~dB}$. Donuzlav wind farm violated them at the territory of Veterok dacha settlement, while it matched them for the adjacent industrial areas.

Donuzlav wind farm affected a part of Novoozyornoe urban settlement, including Rodniki and Veterok dacha settlements. All of them were used for temporary (summer) residences or working places of local agriculture.. We made a rough assessment based on remote sensing images and local statistics and found out that the number of the affected varied from 50 to 500 people depending on the season. Up to 30-40 people might be affected by illegally high noise at night. ${ }^{5}$

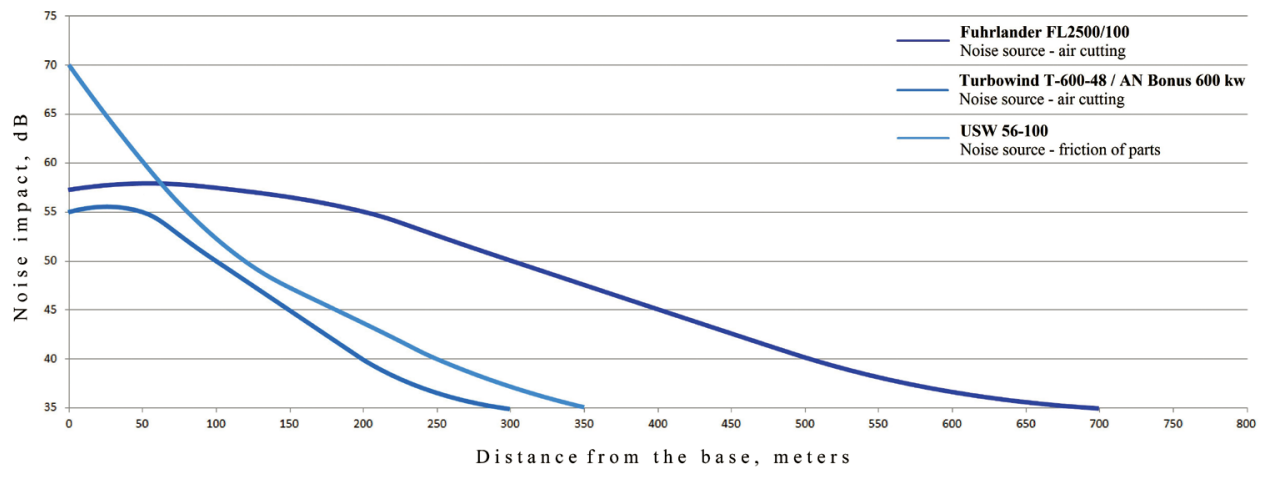

Fig. 7. Noise diagrams for the studied wind turbine models

\footnotetext{
${ }^{4}$ State Committee for Sanitary-Epidemiological Surveillance of the Russian Federation

${ }^{5}$ We would like to emphasize that described situation considers open-air residential areas. The situation with inner space of residential buildings is a bit different and cannot be assessed due to the differences in insulating characteristics of dacha walls.
} 


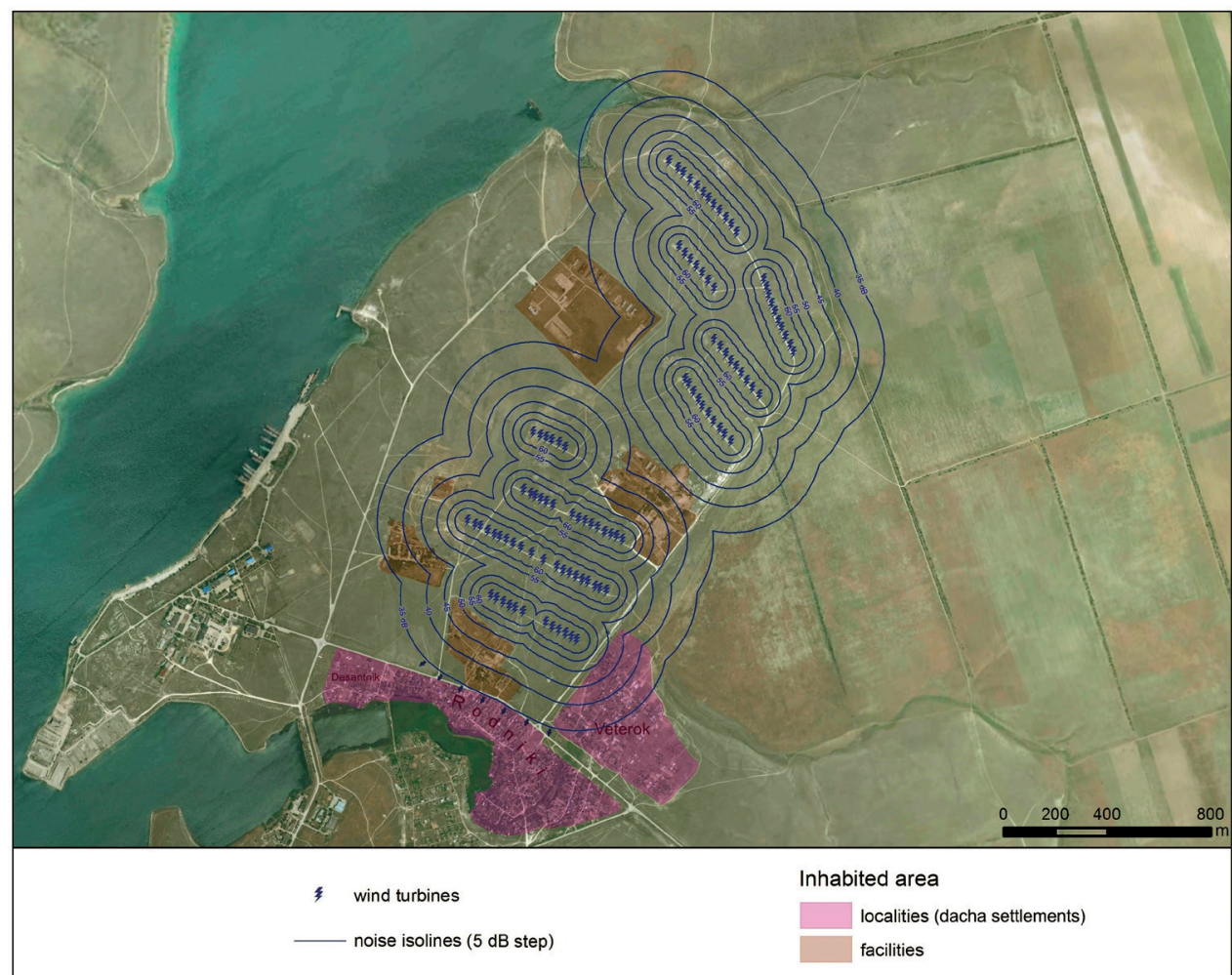

Fig. 8. Donuzlav wind farm noise impact on the surroundings

\section{Visual impact}

Visual impact means changes to the scenic attributes of a landscape connected with introduction of artificial visual elements. Visual impact assessment is of special importance for recreation and heritage territories presenting traditional cultural landscapes. This is the case of Crimea. Visual scenic harmony provides comfortable psychological environment for residents.

Visual impact of wind turbines depends on many aspects including size and design of wind turbines, their number and arrangement of wind farm scheme and surrounding landscape. Thereby overall visual impact varies from negative to positive. Though even a single wind turbine has a visual impact on surroundings, many local people characterized it as a neutral (see the results of our sociological survey below). Such attitude is explained by the fact that people grew up viewing wind farms, adapted to such visual landscape or simply ignored this issue.
Our research demonstrated that the most negative visual impact was registered from Mirnovsky site of Sakskaya wind farm (Fig. 9). It was explained by the design of USW 56-100 wind turbines which 'violated' the background by their wide blades and gray lattice towers. Then, of course, it was the number of wind turbines (155 units) and their compact arrangement in multi-rows. Mirnovsky site of Sakskaya wind farm visually polluted landscape by strengthening the visual effect of its natural monotony character. As we found out, it was better to use wind turbines with tubular towers and place them in one row and further from each other.

In some cases, USW 56-100 wind turbines had positive visual impact on the scenery. And this was the case of Presnovodnenskaya wind farm. Its wind turbines were stretched in a single row along the top of a ridge making it more vivid and improving visual image of scatted steppe hills (Fig. 10). 


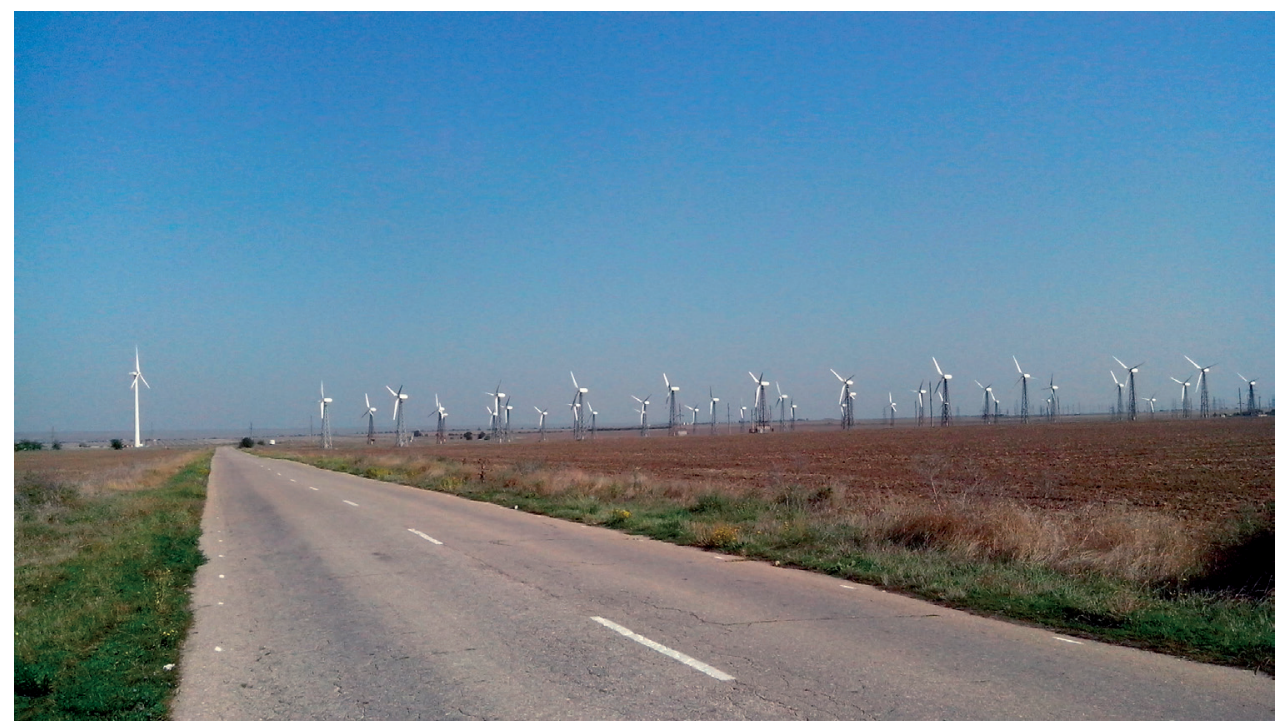

Fig. 9. View of Mirnovsky site of Sakskaya wind farm

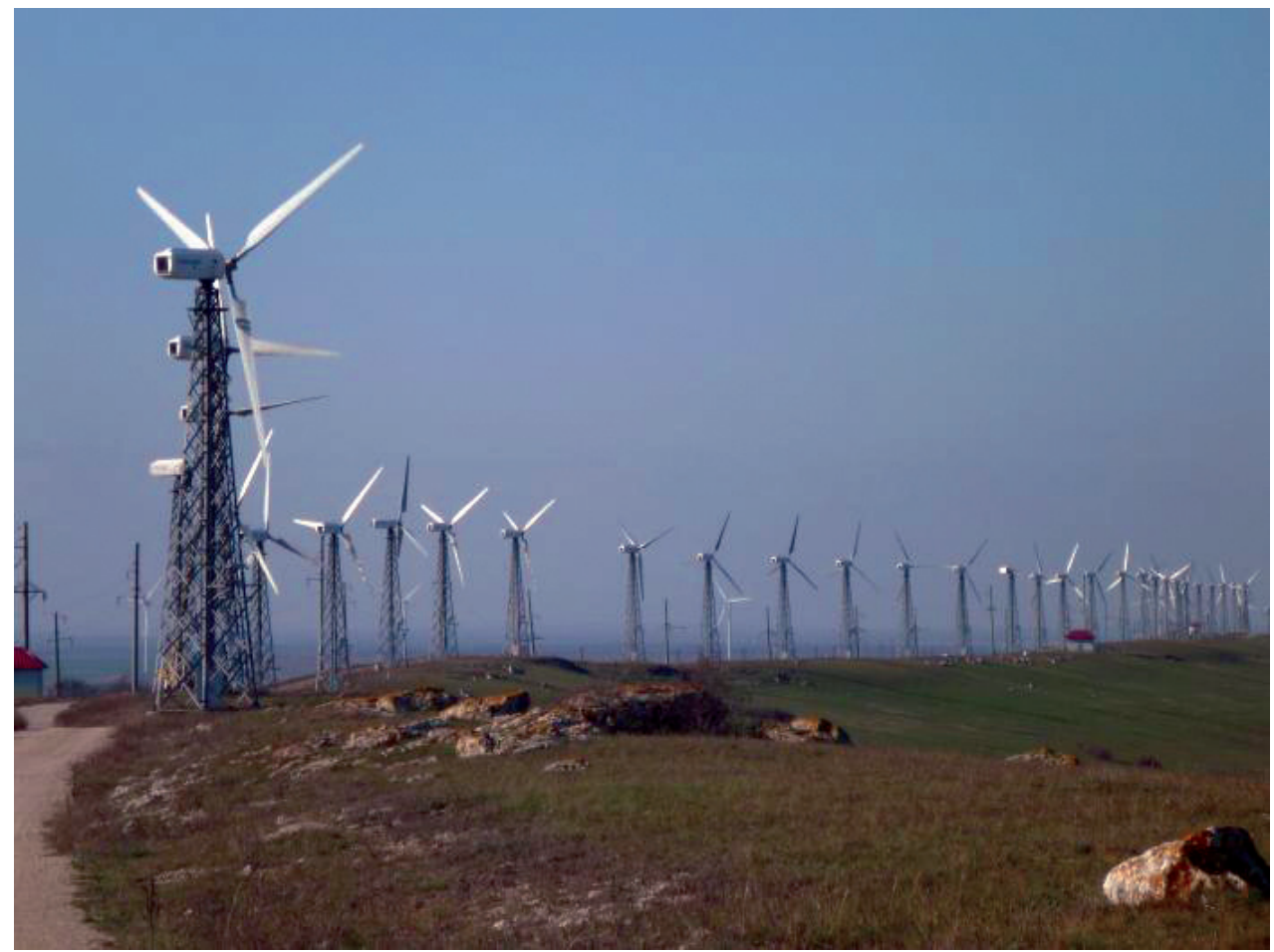

Fig. 10. Outlining the relief - Presnovodnenskaya wind farm (vkerchi.com 2018)

We also marked a positive visual impact of Ostaninskaya wind farm. Its large and spread FL2500 wind turbines became focal objects for the scenery contributing diversity into monotonous steppe landscape (Fig. 11).
Finally, we may conclude the following: the majority of modern wind turbines looked in a standard way - both white tubular towers and elongated blades. This seems optimal for local landscapes visual image. Meanwhile, FL2500 wind turbines were various and the largest of them, tow- 


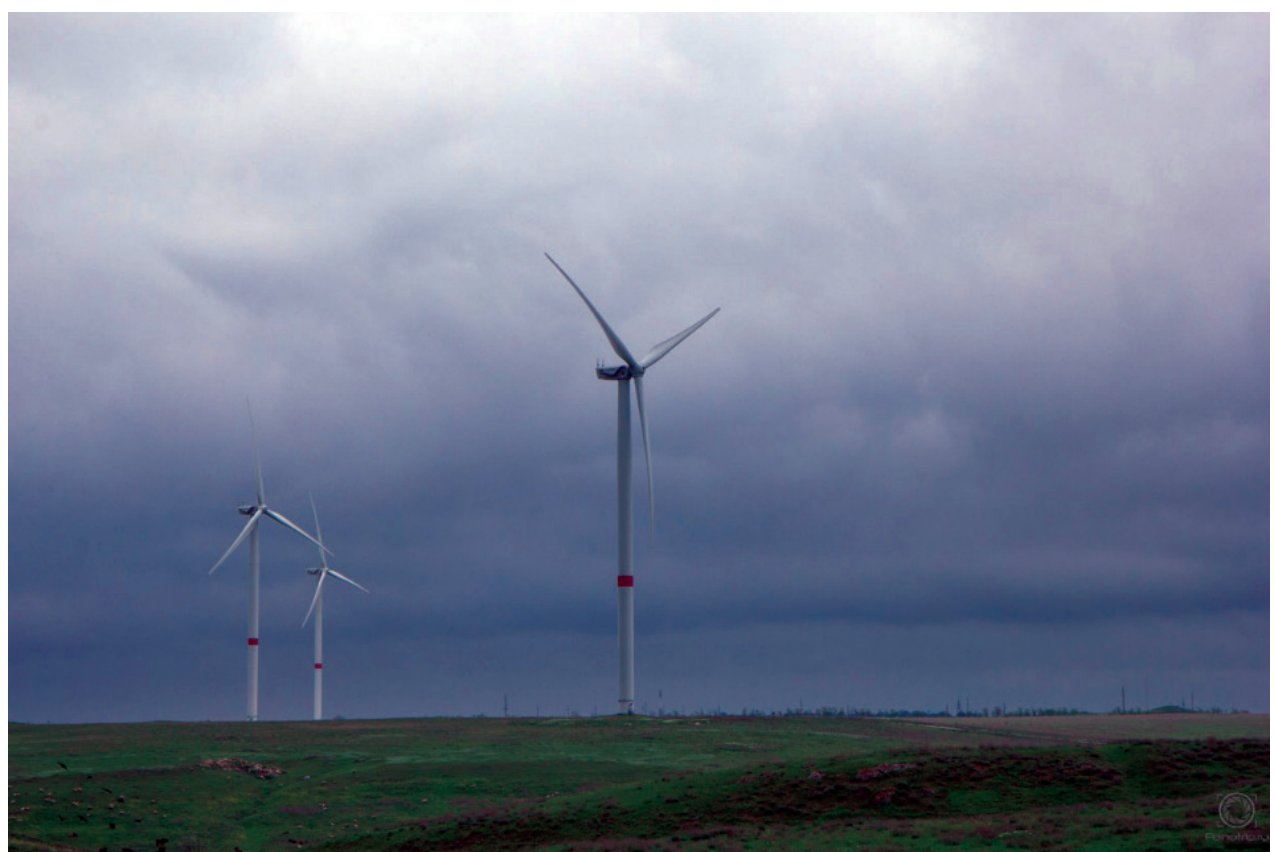

Fig. 11. "Something to catch a glance» - Ostaninskaya wind farm (photo by Andrey Pletmentsev 2017)

ering up to 160 meters, were equipped by a wide lattice tower (Fig. 12). We think that their design violated landscape visual harmony.
The larger wind turbine is the more visual impact is observed. While $18 \mathrm{~m}$ height wind turbines were seen at a distance up to $21 \mathrm{~km}$, modern 80 to $160 \mathrm{~m}$ height

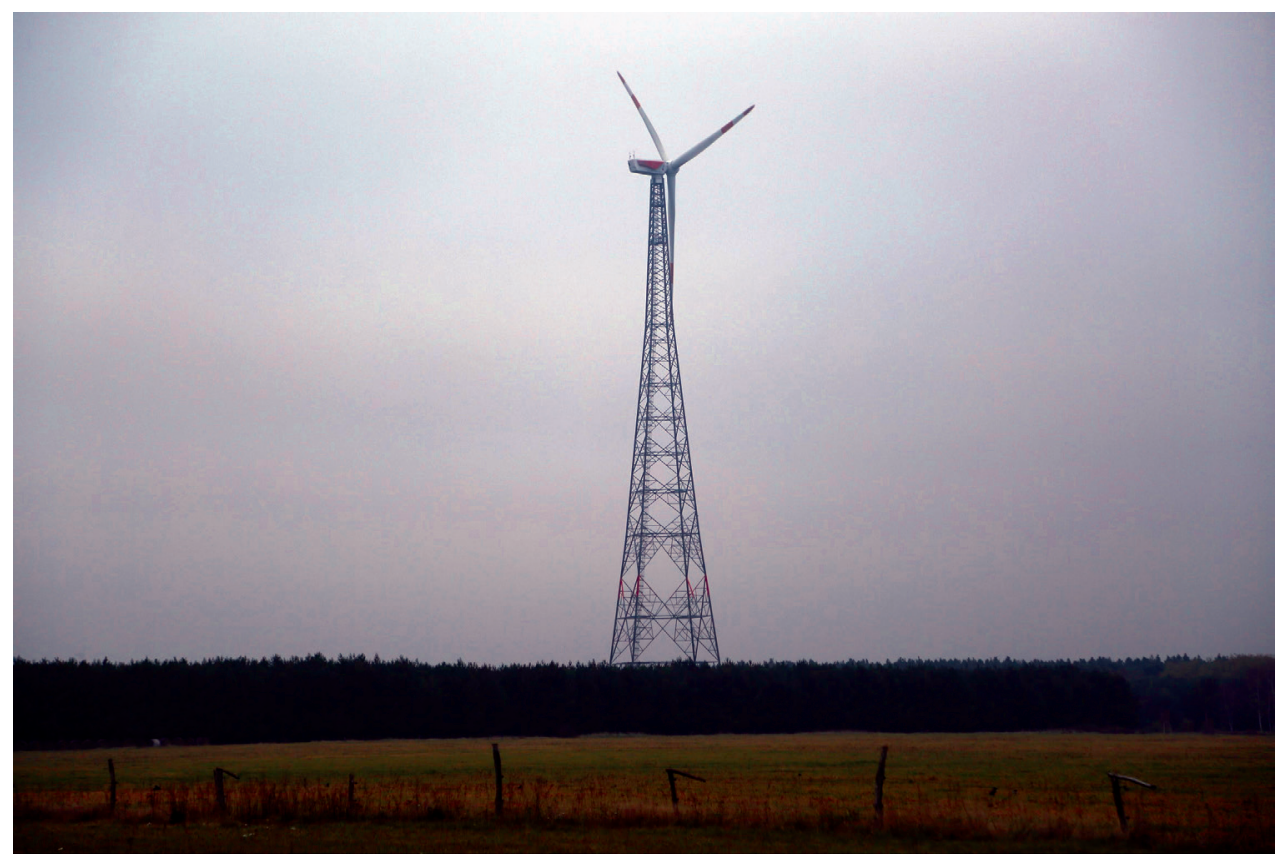

Fig. 12. Dominating the landscape - 160 m height FL2500 tower near Laasow, Germany (photo by Silvio Matysik 2014) 
wind turbines changed the scenery at the distance up to 39 to $53 \mathrm{~km}^{6}$ (Perelman 2010). Another problem was revealed - a new wind farm near the already existing one may damage the visual landscape image more than a single multi-row wind farm (see Fig. 9).

\section{Sociological survey}

Our sociological survey involved people from the vast part of the Crimean Peninsula as we moved from Sakskaya wind farm at the West to Ostaninskaya and Presnovodnenskaya wind farms at the East. We have questioned 106 people ${ }^{7}$ aged 14-75, whose permanent residence was the Crimean Peninsula. During interviews we asked their opinion about noise and visual impact of wind farms and their general view on wind energy based on their personal experience. We tried to make our survey more representative by taking into account answers of respondents who appeared near wind farms regularly or live at the distance about $5 \mathrm{~km}$ from them.

Age structure of respondents was of special interest. Wind farms of the Crimean Peninsula were operating since 1990s. This time period enabled to consider three categories of local population: people 35+, born earlier than the construction of the Crimean wind farms; people from 18 to 35, who grew during construction and operation periods of local wind farms; and people under 18, born when the Crimean wind farms became routine elements of local landscape.
The results of our survey showed that the majority of local people had a positive view on wind farms in the region and did not feel negative effect from them (Fig. 13). Only $6 \%$ of respondents from surrounding localities heard noise from wind turbines and $1 / 3$ of them found it disturbing. ${ }^{8}$ This confirmed the results of our sound level measuring on Ostaninskaya, Presnovodnenskaya and Sakskaya wind farms. Then, more than 2/3 of local residents considered visual impact of wind farms as positive. They supported their development as well.

Comparing results from different age groups (graphs 2 and 3), we found out that the younger generation was more positive in their responses: the share of positive opinions and neutral+positive answers were 83,77 and $62 \%$ for people under 18, from 18 to 35 and 35+ age groups respectively. We noticed an interval in the "positivity share" between people under 35 and the elder group.

\section{CONCLUSION}

This research was based on original methods of environment features studies concerning wind energy development at a local level. The main results are the following:

Arrangement of the studied wind farms was not optimal. This was true for Ostaninskaya wind farm explained by inadequate turbulence or wind rose analysis
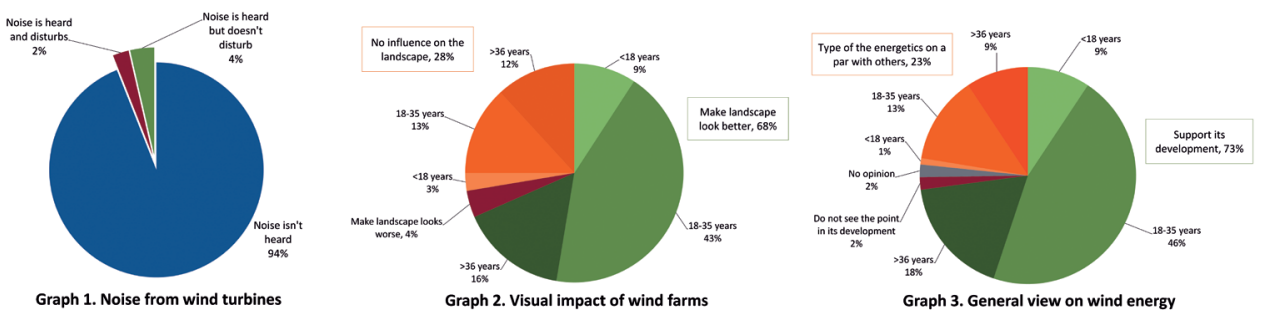

Fig. 13. Local residents' perception of wind farms in Crimea

${ }^{6}$ Considering all assessments - situation with flat relief, clear weather and absence of any ground objects.

${ }^{7}$ Unfortunately, local people were far from willing to participate in the survey as they were inexperienced in this kind. Moreover, many of them were short-term recreational residents spending most of the time on the coastline. 
and Mirnovsky site of Sakskaya wind farm and Presnovodnenskaya wind farm, where losses of generation efficiency were obvious following land use expenses minimization.

Noise impact of wind farms was minimal and did not spread on surroundings- this was confirmed by our field measurements and sociological survey. Nevertheless Donuzlav wind farm assessed virtually violated local health standards of noise impact on residential areas at night.

Visual impact of wind farms varied a lot and had both positive and negative effect in Crimea, but local people opinion was in general positive in this respect.

Local people demonstrated their support to wind energy development in general although they permanently experienced a certain ecological impact.

\section{SUGGESTIONS}

Such assessments may contribute to adequate wind energy use studies at local (wind farm) level. Back to Background section, we want to emphasize once more two aspects of wind farm projecting.

Wind power potential assessments are adequate nowadays but not enough as far as local studies are concerned. More studies of turbulence effect of wind turbines depending on wind turbine model, wind speed and landscape characteristics are necessary.

The least covered aspect of wind farm projecting is an ecological one. While wind energy is environment friendly in general, still it might have a negative effect on environment and local population. Ecological impact assessment should be added to the process of wind farm projecting. Dialogue with local residents, authorities and business might be useful for both economic effectivities of the wind farms and local economic and social development.

\section{REFERENCES}

American Wind Energy Association (2006). Wind Power Myths vs. Facts [online]. Available at: http://web.archive.org/web/20060131235323/http://www.awea.org/pubs/ factsheets/050629_Myths_vs_Facts_Fact_Sheet.pdf (Accessed 24.01.2017).

Baerwald E.F., D'Amours G.H., Klug B.J., Barclay R.M.R. (2008). Barotrauma is a significant cause of bat fatalities at wind turbines. [online] University of Calgary. Available at: http:// www.cell.com/current-biology/abstract/S0960-9822(08)00751-3?_returnURL=http\%3A\% 2F\%2Flinkinghub.elsevier.com\%2Fretrieve\%2Fpii\%2FS0960982208007513\%3Fshowall\%3 Dtrue\&cc $=y=$ (Accessed 21.03.2017).

Bettex M. (2012). Wind resistance. [online] Massachusetts Institute of Technology. Available at: http://news.mit.edu/2010/climate-wind-0312 (Accessed 30.06.2017).

Bolin K., Bluhm G., Eriksson G., Nilsson M.E. (2011). Infrasound and low frequency noise from wind turbines: exposure and health effects. Environmental Research Letters. - v. 6, no. 3.

Brannstrom C., Gorayeb A., de Sousa Mendes J., Loureiro C., de Andrade Meireles A.J., da Silva E.D., de Freitas A.L.R., de Oliveira R.F. (2017). Is Brazilian wind power development sustainable? Insights from a review of conflicts in Ceará state. Renewable and Sustainable Energy Reviews, v.67, p. 62-71.

climate-data.org (2017). Climate: Autonomous Republic of Crimea [online]. Available at: https://ru.climate-data.org/region/619/ (Accessed 07.09.2017). 
Dillon M. and Tronstad L. (2012). Baseline Research for Long-term Effects of Wind Farms on Insects in Wyoming. [online] University of Wyoming. Available at: https://www.uwyo.edu/ wyndd/_files/docs/reports/wynddreports/u13dil01wyus.pdf (Accessed 25.09.2016).

Elistratov V.V. and Kuznetsov M.V. (2003). Theoretical basis for unconventional and renewable energy. Saint-Petersburg: SPbSPU Publishing House (in Russian).

The Federal Service for State Registration, Cadastre and Cartography of Russian Federation (2017). Public cadastral map. [online] Rosreestr. Available at: https://pkk5.rosreestr.ru/ (Accessed 05.12.2017).

Filin V.A. (1997). Videoecology. Moscow: TASS-Reklama (in Russian).

Furhlander Windtechnology (2017). Kerchensky wind park (Ostaninskaya wind farm) [online]. Available at: http://fwt.com.ua/ветропарк-останинский/ (Accessed 02.09.2017) (in Russian).

Gismeteo (2017). Weather Diary [online]. Available at: https://www.gismeteo.ru/diary/ (Accessed 07.09.2017) (in Russian).

International Renewable Energy Agency (2018). Data and Statistics [online]. Available at: http://resourceirena.irena.org/gateway/dashboard/index.html (Accessed 01.03.2018).

Keith D.W., DeCarolis J.F., Denkenberger D.C., Lenschow D.H., Malyshev S.L., Pacala S., Rasch P.J. (2004). The influence of large-scale wind power on global climate. [online] Proceedings of the National Academy of Sciences of the United States of America. Available at: http:// www.pnas.org/content/101/46/16115.full (Accessed 22.09.2016).

Kommersant (2016). Energy supply of Crimea has been reestablished [online]. Available at: https://www.kommersant.ru/doc/3106583 (Accessed 02.09.2017) (in Russian).

Krymsky Telegraf (2013). How much resources Crimea needs and what is its energy potential?. Krymsky Telegraf newspaper, v. 216 (in Russian).

Leventhall G. (2003). A Review of Published Research on Low Frequency Noise and its Effects. [online] U.K. Department for Environment, Food and Rural Affairs. Available at: http://archive.defra.gov.uk/environment/quality/noise/research/lowfrequency/ documents/lowfreqnoise.pdf (Accessed 01.10.2016).

Lopucki P. and Perzanowski K. (2018). Effects of wind turbines on spatial distribution of the European hamster. Ecological Indicators, v. 84, p. 433-436.

Mikolajczak J., Borowski S., Marć-Pieńkowska J., Odrowaz-Sypniewska G., Bernacki Z., Siódmiak J., Szterk P. (2013). Preliminary studies on the reaction of growing geese (Anser anser $f$. domestica) to the proximity of wind turbines. Polish Journal of Veterinary Sciences, v. 16(4), p. 679-686.

Meyers J. and Meneveau C. (2012). Optimal turbine spacing in fully developed windfarm boundary layers. [online] Wind Energy. Available at: https://people.mech.kuleuven. be/ jmeyers/resources/downloads/WE2012_15_305-preprint.pdf (Accessed 01.10.2016).

Ministry of Energy of Russian Federation (2017). Energy supply of Crimean Peninsula. [online] Available at: https://minenergo.gov.ru/sites/default/files/texts/Энергосистема\%20Kрыма_на\%20сайт.pdf (Accessed 02.09.2017) (in Russian). 
Mitchell P. (2014). Wind turbine separation distances matter. [online] Waubra Foundation. Available at: https://waubrafoundation.org.au/resources/mitchell-p-wind-turbineseparation-distances-matter/ (Accessed 04.02.2018).

New Zealand Wind Energy Association (2017). Visual Effects. [online] Available at: http:// www.windenergy.org.nz/visual-effects (Accessed 04.02.2018).

Nikolaev V.A. (2005). Landscape science. Aesthetics and design. Moscow: Aspect Press (in Russian).

Perelman Y.I. (2010). Horizon. Entertaining geometry. Moscow: Rimis (in Russian).

Rabl A. and Spadaro J. (2005). Externalities of Energy: Extension of accounting framework and Policy Applications. [online] European Community, EESD Programme. Available at: http://www.externe.info/externe_2006/expoltec.pdf (Accessed 14.09.2016).

Regnum (2017). Energy supply of Crimea and Sevastopol has been reestablished [online]. Available at: https://regnum.ru/news/2307920.html (Accessed 02.09.2017) (in Russian).

RIA News Crimea (2015). The development of Crimean energy supply system [online]. Available at: http://crimea.ria.ru/infographics/20151215/1102118990.html (Accessed 02.09.2017) (in Russian).

Russian Association of Wind Industry (2018). The first wind farm in Russia was launched in Ulyanovsk. A new history of wind power in Russia [online]. Available at: https://rawi.ru/en/ the-first-wind-farm-in-russia-was-launched-in-ulyanovsk-a-new-history-of-wind-powerin-russia/ (Accessed 01.03.2018).

Samorani M. (2010). The Wind Farm Layout Optimization Problem . [online] Leeds School of Business, University of Colorado. Available at: https://www.researchgate.net/ publication/242580464_The_Wind_Farm_Layout_Optimization_Problem (Accessed 08.09.2017).

Semyonov V.G. (2014). Crimean energetics. What is to build? . [online] Energosovet Journal. Available at: http://www.energosovet.ru/bul_stat.php?idd=472 (Accessed 02.09.2017) (in Russian).

SM news (2017). Aksyonov gave 72 hours for energy supply reestablishment for Crimea [online]. Available at: https://sm-news.ru/news/energetika/aksenov-otvel-72-chasa-navosstanovlenie-elektrosnabzhenie-kryma/ (Accessed 02.09.2017) (in Russian).

State Committee of Sanitary-Epidemiological Surveillance of Russian Federation (2017). Health standards HS 2.2.4/2.1.8.562-96 "The noise at work, in the spaces of residential, public buildings and on residential areas" (established by Decree №36 at October, 31, 1996). Moscow: Morkniga (in Russian).

SUE Crimean Generating Systems (2017). Business units [online]. Available at: http://www. energysystem-crimea.ru/производство.html (Accessed 04.09.2017) (in Russian).

System Operator of United Power System (2018). 2017 Russian United Power System functioning report [online]. Available at: http://so-ups.ru/fileadmin/files/company/ reports/disclosure/2018/ups_rep2017.pdf (Accessed 01.03.2018) (in Russian). 
UK Department of the Environment (2007). Draft Planning Policy Statement 18: Renewable Energy [online]. Available at: http://www.planningni.gov.uk/index/policy/planning_ statements_and_supplementary_planning_guidance/pps18-draft-renewable-energy. pdf (Accessed 08.09.2017).

Ved'I.P. (2000). Climatic atlas of Crimea. Simferopol : Tavriya-Plyus (in Russian).

Wilson S. (2002). Guidelines for Landscape \& Visual Impact Assessment. London: Spon Press.

Received on September $21^{\text {st }}, 2018$

Accepted on February $20^{\text {th }}, 201$ 